\title{
HEXAVALENT CHROMIUM-INDUCED ALTERATION OF CARBOHYDRATE BIOENERGETICS: A DOSE-DEPENDENT STUDY
}

\author{
KANU SHIL, SUDIPTA PAL* \\ Department of Human Physiology, Nutritional Biochemistry and Toxicology Laboratory, Tripura University, Suryamaninagar, \\ West Tripura, Tripura, India. Email: sudiptapal@tripurauniv.in \\ Received: 03 November 2016, Revised and Accepted: 15 November 2016
}

\section{ABSTRACT}

Objective: This study was conducted to observe the dose-dependent effect of $\mathrm{Cr}$ (VI) on certain aspects of carbohydrate metabolism in mice with four different doses, viz., $5 \mathrm{mg} / \mathrm{kg}, 10 \mathrm{mg} / \mathrm{kg}, 15 \mathrm{mg} / \mathrm{kg}$ and $20 \mathrm{mg} / \mathrm{kg}$ b.w., respectively, for 30 days of exposure.

Methods: Blood glucose, glycogen content, and pyruvic acid of liver tissue were determined to evaluate the glycolytic activity. Enzymes such as isocitrate dehydrogenase (IDH), succinate dehydrogenase, and malate dehydrogenase (MDH) activities were measured to determine the tricarboxylic acid cycle function. In addition, nicotinamide adenine dinucleotide (NADH) ubiquinone $\mathrm{C}$ oxidoreductase activity was estimated to evaluate the alteration in oxidative phosphorylation pathway with dose-dependent chromium exposure. Total protein, free amino acid nitrogen, and transaminase enzyme activity were also measured.

Results: Chromium exposure caused marked depletion of blood glucose and liver glycogen contents in a dose-dependent manner. The activities of IDH, succinate dehydrogenase, and MDH were significantly altered in a dose-specific manner by chromium exposure. Relevant exhaustion of glycolytic substrates was noted in the form of reduced pyruvate content in hepatocytes following chromium exposure. In addition, the treatment caused elevation of free amino nitrogen associated with depletion of total protein content and elevated transaminase enzyme activities in hepatocytes. Significant alteration of mitochondrial NADH-ubiquinone C oxidoreductase activity was also noted

Conclusion: By analyzing the observed results, it can be suggested that $\mathrm{Cr}$ (VI) exerts hypoglycemic and glycogenolytic effects associated with alteration of citric acid cycle and electron transport pathways in hepatocytes in a dose-specific manner thus resulting in serious alteration in the carbohydrate bioenergetics and mitochondrial energy generation in hepatic cells.

Keywords: Hexavalent chromium, Hypoglycemia, Glycogenolysis, Citric acid cycle, Electron transport chain.

(c) 2017 The Authors. Published by Innovare Academic Sciences Pvt Ltd. This is an open access article under the CC BY license (http://creativecommons. org/licenses/by/4. 0/) DOI: http://dx.doi.org/10.22159/ajpcr.2016.v10i2.16019

\section{INTRODUCTION}

Chromium (Cr) is a naturally occurring transition metal; usually found in rocks, volcanic eruption, soil as well as plant and animals. It exists in various oxidation states ranging from divalent to hexavalent state [1]. Potassium dichromate $\left(\mathrm{K}_{2} \mathrm{Cr}_{2} \mathrm{O}_{7}\right)$ and sodium chromate are the most important inorganic salts of hexavalent chromium (Cr [VI]) which have been widely used in numerous industrial processes such as metallurgy, tannery effluents, chrome plating, chemical industry, textile manufacture, wood preservation, photography and photoengraving, refractory and stainless steel industries and cooling systems [2,3]. As a result of globalization and exhaustive industrialization, heavy metal pollution amplified significantly throughout the world, among them the top seven countries which produce a larger amount of industrial effluents containing $\mathrm{Cr}$ (VI) are South Africa, India, Kazakhstan, Zimbabwe, Finland, Brazil, and Turkey [4]. According to the study of Banerjee et al., there is a trace amount of chromium present in the ground water of Tripura, regarding the WHO limit of chromium concentration [5]

Cr (VI) can penetrate through the cell membrane more easily than the other chromium compounds thus executing its potential toxic manifestation, and the severity of chromium toxicity depends on its valence state [6]. Chromate and dichromate are highly soluble in the water and thus readily absorbed by the gastrointestinal tract due to its high diffusional capacity through all types of the cell membrane [7]. Once inside the cell, $\mathrm{Cr}$ (VI) is metabolized to trivalent chromium, either enzymatically (via microsomal enzymes), or non-enzymatically (via ascorbate and glutathione) [8]. This intracellular reduction yields reactive intermediates, chromium (V), and chromium (IV).
These reactive intermediates are formed along with oxygen radicals generated via Fenton-like and other possible reactions that occur during intracellular reduction [9], which also intensively trigger the massive production of reactive oxygen species causing oxidative damage, protein cross-linkage, genomic instability and apoptosis, destruction of cellular protein, lipid and DNA $[10,11]$

Main target organs of $\mathrm{Cr}$ (VI) toxicity are lungs, liver, intestine, oral mucosa, nasal mucosa, kidney and brain [11], where it causes lung cancer, stomatitis, gingivitis, perforation of nasal septum, skin ulceration, and necrosis of liver and kidney [12]. The liver is the main organ responsible for the metabolism, detoxification and secretory function of the organism; it regulates plenty of metabolic pathways of mammalian systems [13]. Epidemiological studies show that $\mathrm{Cr}$ (VI) causes hepatotoxicity in human and laboratory animals primarily through oxidative stress-mediated mechanism [14]. Tubular necrosis occurs in the kidney due to the exposure of $\mathrm{Cr}(\mathrm{VI})$, acute exposure causes liver and kidney damage and also responsible for the deterioration of organ structure [15]. A number of study reports show that $\mathrm{Cr}$ (VI) compound is also responsible for gastrointestinal bleeding from ulceration of intestinal mucosa, cardiovascular shock, kidney, and liver damage [16,17]. Sub-chronic exposure of $\mathrm{Cr}$ (VI) shows a significant decline in the levels of antioxidant parameters of liver and parallel increase in the lipid peroxidation [18], indicative of oxidative damage in tissue.

Metabolic dysfunction is one of the important mechanisms of chromium toxicity in various organ systems including liver. $\mathrm{Cr}$ (VI) exposure produces histiocytic cellular infiltration of hepatic and renal tissue owing to anomalies in carbohydrate and protein metabolism by 
retarding rate limiting irreversible biochemical reactions of various crucial metabolic pathways [19]. It also leads to oliguria and proteinuria in mammalian system [15]. Cr (VI) is actively associated with alteration of normal cell to neoplastic state accompanied by extensive metabolic reprogramming mainly at the level of energy transducing processes through changes in enzymatic qualities and intracellular pools of their substrate and intermediator biomolecules [20]. There was least information about the dose-dependent toxicity study of $\mathrm{Cr}(\mathrm{VI})$ relating substrate and enzymological parameters of carbohydrate metabolism. The aim of the study is to provide a framework for the understanding the dose-dependent mechanism of $\mathrm{Cr}$ (VI) toxicity concerning carbohydrate metabolism in the experimental animal model.

\section{METHODS}

Materials

Potassium dichromate $\left(\mathrm{K}_{2} \mathrm{Cr}_{2} \mathrm{O}_{7}\right.$ molecular weight: 294.185) procured from Sigma-Aldrich (India), chemicals such as sodium succinate, triethanolamine, sodium citrate, sucrose, diethyl ether, bovine serum albumin (BSA), $\mathrm{KOH}$, ethanol, $\mathrm{H}_{2} \mathrm{SO}_{4}$, phenol, Tris- $\mathrm{HCl}$, dichlorophenolindophenol, and ethylene diamine tetraacetic acid (EDTA). Were of analytical grade and purchased from Merck (India), SRL (India), Sigma-Aldrich (India). Biochemical kit such as glucose estimation kit was purchased from Coral clinical systems. Ultrapure water by Millipore was used throughout the experiment to avoid metal contamination in the preparation of reagents.

\section{Animals}

For this study, Swiss albino male mice $(n=30)$ weighing $30-35$ g were purchased from CPCSEA registered animal supplier. They were housed in polypropylene cages, acclimatized under laboratory conditions for 1 week before starting the experiment. Animals were provided with standard protein diet (18\% casein diet) and supplied with drinking water ad-libitum throughout the experiment. They were kept in animal house by maintaining standard air conditions of temperature $\left(22^{\circ} \mathrm{C}-25^{\circ} \mathrm{C}\right)$ with $12 \mathrm{hrs}$ alternating light and dark cycles.

\section{Metallic salt selected}

Chromium salts are available in various salts forms such as chlorides, sulfates, and nitrates and acetates which are more or less soluble in water. The degree of solubility depends on the hardness and temperature of water. As $\mathrm{K}_{2} \mathrm{Cr}_{2} \mathrm{O}_{7}$ is more soluble in deionized water, pure salt of $\mathrm{K}_{2} \mathrm{Cr}_{2} \mathrm{O}_{7}$ with molecular formula $\mathrm{K}_{2} \mathrm{Cr}_{2} \mathrm{O}_{7}$ and molecular weight 294.18 was used in this study.

\section{Experimental design}

Initially, the animals were divided into two groups of equal average body weight, the control, and Cr (VI)-treated groups. Further, the animals of the $\mathrm{Cr}$ (VI)-treated group were subdivided into four separate groups for dose-dependent study. The animals of each group were six in number $(n=6)$, and they were subjected to the following treatment protocol.

\section{Control group}

Animals received normal saline $(0.9 \% \mathrm{NaCl})$ orally.

\section{Chromium-treated groups}

Group I - The animals of this group were treated with hexavalent chromium (as $\mathrm{K}_{2} \mathrm{Cr}_{2} \mathrm{O}_{7}$ ) at a dose of $5 \mathrm{mg} / \mathrm{kg} \mathrm{b.w./day} \mathrm{orally} \mathrm{for}$ 30 days).

Group II - The animals were treated with chromium at a dose of $10 \mathrm{mg} / \mathrm{kg}$ b.w./day orally for 30 days.

Group III - The animals of this group received chromium at a dose of15 mg/kg b.w./day orally for 30 days.

Group IV - Treated with potassium dichromate at a dose of $20 \mathrm{mg} / \mathrm{kg}$ b.w./day orally for 30 days.

\section{Animal sacrifice}

After the treatment was over, all the animals were sacrificed by cervical dislocation following the guideline of the Institutional Animal Ethical Committee.

\section{Collection of blood}

Blood was collected from the hepatic vein of all experimental animals and refrigerated at $-20^{\circ} \mathrm{C}$ until biochemical analyses were performed.

\section{Separation of tissue}

After sacrifice, liver tissue was collected from all the animals, washed in ice-cold saline $(0.9 \%)$, blotted dry, weighed and kept at $-20^{\circ} \mathrm{C}$ for biochemical analyses. Liver from control and one of the treated groups (Group II) was taken and fixed in 10\% (pH 7.4) neutral buffered formalin solution and processed for histopathological evaluation.

\section{Preparation of tissue homogenate}

The tissue homogenate was prepared in suitable buffer solution (e.g., 0.1 M phosphate buffer, $\mathrm{pH} 7.4,0.25 \mathrm{M}$ sucrose solution) as required for different analytical methods using Potter Elvenjem glass homogenizer.

\section{Isolation of mitochondria from liver tissue}

The mitochondria of liver tissue was isolated according to the method of Dutta et al. [21]. A portion of the liver tissue was cleaned and cut into small pieces. $500 \mathrm{mg}$ of the tissue were placed separately in $10 \mathrm{ml}$ of sucrose buffer $(0.25$ [M] sucrose, 0.001 [M] EDTA, 0.05 [M] Tris- $\mathrm{HCl}[\mathrm{pH} 7.8])$ at $25^{\circ} \mathrm{C}$ for 5 minutes. The tissue was then homogenized separately in cold for 1 minute at low speed using a Potter Elvenjem glass homogenizer (Belco Glass Inc., Vineland, NJ, USA). The homogenate was centrifuged at $1500 \mathrm{rpm}$ for 10 minutes at $4^{\circ} \mathrm{C}$. This supernatant was centrifuged at $4000 \mathrm{rpm}$ for 5 minutes at $4^{\circ} \mathrm{C}$. The supernatant, thus obtained, was further centrifuged at $14,000 \mathrm{rpm}$ for 20 minutes at $4^{\circ} \mathrm{C}$. The final supernatant was discarded, and the pellet was re-suspended in sucrose buffer and stored at $-20^{\circ} \mathrm{C}$ until further analysis. However, most of the enzymatic assays were carried out with freshly prepared mitochondrial suspension.

\section{Morphophysiological analyses}

Body weight and organosomatic index

The body weight of each animal of each group was taken onward the commencement day of treatment and also noted periodically until sacrifice to observe the changes in body weight in different groups. The organ weight (whole liver) of respective group of animals was also recorded after sacrifice of the animals. From these, organosomatic index (OSI) of the liver was calculated [22].

$$
\text { Organo }- \text { somatic index }=\frac{\text { Weight of the organ }(\mathrm{g})}{\text { Day } 30^{\text {th }} \text { total body weight }} \times 100
$$

\section{Biochemical analyses}

\section{Liver glycogen content}

To determine the glycogen content of liver tissue the method of Montgomery [23] was used. In brief, approximately $300 \mathrm{mg}$ of liver tissue was mixed with $1 \mathrm{ml}$ of $30 \% \mathrm{KOH}$ solution and placed in a boiling water bath for 15-20 minutes and then cooled at room temperature. It was then added with ethanol, again heated and cooled at room temperature. The mixture was centrifuged at $3000 \mathrm{rpm}$ for 10 minutes, and the supernatant was discarded. Ethanol washing was repeated twice, and the resultant precipitate was taken for the estimation of glycogen. The glycogen content was expressed in terms of $\mathrm{mg} / \mathrm{g}$ of liver tissue.

\section{Blood glucose level}

Glucose contents of blood samples were measured by GOD-POD kit method following the method of Barham and Trinder [24]. Briefly, $1 \mathrm{ml}$ of the working reagent was mixed with $10 \mu \mathrm{l}$ of the sample and incubated for $10-15$ minutes at $37^{\circ} \mathrm{C}$. Similarly, a blank and a standard were prepared using $10 \mu \mathrm{l}$ of distilled water and a standard solution, respectively. After the incubation, the absorbance was taken at $500 \mathrm{~nm}$. The level of blood glucose was expressed as $\mathrm{mg} / \mathrm{dl}$.

\section{Liver pyruvic acid content}

The liver pyruvic acid content was estimated according to the protocol of Segal et al. [25]. Briefly, 10\% tissue homogenate was centrifuged at 
$3000 \mathrm{rpm}$ for 10 minutes, with 5\% tricarboxylic acid cycle (TCA). The resultant supernatant was mixed with $1 \mathrm{ml}$ distilled water and $0.5 \mathrm{ml}$ 2, $4 \mathrm{DNPH}$ and shaken it for 3 minutes. Then, toluene was added and mixed vigorously by hand shaking for few min. After that added, $2 \mathrm{ml}$ of sodium carbonate and sodium hydroxide solution each to measure the optical density at $420 \mathrm{~nm}$. The observed result was expressed as $\mathrm{mg} \%$.

\section{Determination of the activity of TCA cycle}

Isocitrate dehydrogenase (IDH) activity

Mitochondrial IDH activity was measured according to the method of King [26]. To $0.1 \mathrm{ml}$ of Tris- $\mathrm{HCl}, 0.2 \mathrm{ml}$ of trisodium isocitrate, $0.3 \mathrm{ml}$ of manganese chloride, $0.2 \mathrm{ml}$ of mitochondrial suspension and $0.2 \mathrm{ml}$ of NADP $(0.2 \mathrm{ml}$ of saline for control) were added. After incubation, $0.001 \mathrm{M}$ of DNPH was added followed by $0.005 \mathrm{M}$ of EDTA and then $0.4 \mathrm{~N}$ $\mathrm{NaOH}$ was added, OD was taken at $420 \mathrm{~nm}$ in an UV spectrophotometer. The enzyme activity was expressed as unit $/ \mathrm{min} / \mu \mathrm{g}$ of protein.

\section{Succinate dehydrogenase (SDH) activity}

The SDH activity was measured spectrophotometrically by following the reduction of $\mathrm{K}_{3} \mathrm{Fe}(\mathrm{CN})_{6}$ at $420 \mathrm{~nm}$ according to the method of Dutta et al. [21]. $1 \mathrm{ml}$ of the assay mixture contained $50 \mathrm{mM}$ phosphate buffer $(\mathrm{pH} 7.4), 2 \%(\mathrm{w} / \mathrm{v}) \mathrm{BSA}, 4 \mathrm{mM}$ succinate, $2.5 \mathrm{mM} \mathrm{K}_{3} \mathrm{Fe}(\mathrm{CN})_{6}$ and a suitable aliquot of the enzyme. The enzyme activity was expressed as units $/ \mathrm{min} / \mathrm{mg}$ of tissue protein.

\section{Assay of malate dehydrogenase (MDH)}

This enzyme activity was determined by the method of Mehler et al. [28] using an assay mixture containing potassium phosphate buffer, $0.0076 \mathrm{M}$ oxaloacetic acid and $0.005 \mathrm{M}$ nicotinamide adenine dinucleotide (NADH) at pH 7.4. The reduction of NADH was measured at $340 \mathrm{~nm}$ for $5 \mathrm{~min}$ with 10 seconds interval and expressed the activity as mmole of NADH oxidized $/ \mathrm{min} / \mathrm{mg}$ of protein.

\section{Determination of the activity of electron transport chain \\ NADH: Ubiquinone C oxidoreductase activity}

Theactivity of NADH:UbiquinoneCoxidoreductase(NADH dehydrogenase) was measured by the method of Minakami et al. [29]. The reaction mixture contained $1 \mathrm{ml}$ phosphate buffer, $0.1 \mathrm{ml}$ of potassium ferricyanide and $0.2 \mathrm{ml}$ mitochondrial suspension in a total reaction volume of $3 \mathrm{ml}$ with distilled water. Freshly prepared $(0.1 \%)$ NADH solution was added just before the addition of the enzyme except the control set. The change in the OD was measured at $420 \mathrm{~nm}$ for 3 minutes and the enzyme activity was expressed as mmole of NADH oxidized/min/mg of protein.

Determination of total protein content and gluconeogenic substances

\section{Tissue protein content}

The protein content was estimated according to the method of Lowry et al. [30]. To $0.1 \mathrm{ml}$ of tissue homogenate, $0.9 \mathrm{ml}$ of water and $4.5 \mathrm{ml}$ of alkaline copper reagent were added and kept at room temperature for $10 \mathrm{~min}$. To this, $0.5 \mathrm{ml}$ of Folin's reagent (1:2) was added and the blue color developed was read after 20 minutes at $640 \mathrm{~nm}$. Protein content was expressed as $\mathrm{mg} \%$.

\section{Free amino acid nitrogen content}

The $5 \%$ tissue homogenate (in $0.1 \mathrm{M} \mathrm{PB}, \mathrm{pH} 7.4$ ) was first dissolved in $0.67(\mathrm{~N}) \mathrm{H}_{2} \mathrm{SO}_{4}$ and $10 \% \mathrm{Na}$-tungstate to precipitate proteins and then centrifuged to get the protein-free extract. The resultant supernatant was treated with cyanide acetate buffer and 3\% ninhydrin solution as per the protocol proposed by Rosen [31]. After that, the solution was heated at $100^{\circ} \mathrm{C}$ in a water bath for 5 minutes and immediately after cooling added with isopropanol to develop a violet color. Optical density of that colored solution was measured in a spectrophotometer at $570 \mathrm{~nm}$.

Glutamate pyruvate transaminase (GPT) and glutamateoxaloacetate transaminase (GOT) activities

The transaminase enzyme activities in the studied tissue were determined following the method of Reitman and Frankel [32]. For this assay, the standard kit (Coral clinical systems, Goa, India) was used to measure photometrically the color intensity of the reaction mixture. In general, the color was formed due to the chemical of reaction of alanine with $\alpha$-ketoglutarate to form pyruvate in the case of GPT, whereas the aspartate was used to react with $\alpha$-ketoglutarateto originate pyruvate in the case of GOT. After this enzymatic reaction, all the tubes were allowed to incubate at $37^{\circ} \mathrm{C}$ for a specific period of time and absorption noted at $505 \mathrm{~nm}$. The enzyme activity was expressed in terms of units/ mg of tissue.

\section{Histological study}

For histopathology of the liver of both control and Cr (VI) treated mice were preserved in 10\% neutral buffered formalin solution for $24 \mathrm{hrs}$. After proper dehydration in graded alcohol, clearing, impregnation and embedding, tissue sections were prepared by rotary microtome. These sections obtained from the respective groups were stained using hematoxylin-eosin and examined under both low and power of microscope and photomicrographs were taken using $\times 20$ objective.

\section{Statistical analysis of data}

The statistical analyses were performed by Student's t-test and values were expressed as means \pm standard error of mean. The minimum criterion for statistical significance was set at $\mathrm{p}<0.05$

\section{RESULTS}

Changes in the body weight following sub-acute chromium exposure have been represented in Table 1 which reveals that chromium treatment at the present dose and duration has no significant effect on the body weight changes of experimental mice.

It is further shown in Table 1 at chromium intoxication affects the organo-somatic index of mice liver. The liver-somatic index (LSI) was increased gradually in all the treated groups of mice in a dosedependent manner. The changes were observed as follows: In Group I, it was 7.51\% ( $\mathrm{p}<0.01)$, in Group II, 10.65\% (p>0.05), in Group III, 9.93\% $(\mathrm{p}<0.05)$ and in Group IV 21.54\% $(\mathrm{p}<0.01)$.

Table 2 demonstrates that hexavalent chromium exposure significantly altered the blood glucose level. The percentage of decrease was highest in Group II (58.27\%; p<0.01) and less in Group IV $(10.73 \%$, $\mathrm{p}<0.05$ ); although the glucose content decreased in Group I and III, the percentage changes were observed as $18.46 \%(p<0.05)$ and $52.37 \%$ $(\mathrm{p}<0.01)$, respectively.

It is revealed from Table 2 that the glycogen content of liver of chromium-treated mice significantly decreased gradually. The percentage of decreased glycogen content observed was 3.7\% $(\mathrm{p}<0.05), 20.98 \%(\mathrm{p}<0.05), 42.58 \%(\mathrm{p}<0.05)$ and $70.06 \%(\mathrm{p}<0.05)$ in Groups I, II, III and IV, respectively.

It is revealed from Table 2 at $\mathrm{Cr}$ (VI) exposure results in gradual decrease in pyruvic acid content of hepatic tissue in a dose-specific manner. The decreasing pattern was as follows: $42.32 \%(\mathrm{p}<0.05), 48.12 \%$

Table 1: Effects of four different doses of $\mathrm{Cr}$ (VI) on body weight and LSI

\begin{tabular}{lll}
\hline $\begin{array}{l}\text { Groups of } \\
\text { animals (n=6) }\end{array}$ & $\begin{array}{l}\text { Final body } \\
\text { weight } \mathbf{( g )} \text { after } \\
\text { 30 days }\end{array}$ & $\begin{array}{l}\text { LSI liver weight } \times \mathbf{1 0 0 / b o d y} \\
\text { weight } \mathbf{( g )}\end{array}$ \\
\hline Control & $35.75 \pm 3.07$ & $4.13 \pm 0.23$ \\
Group I & $39.03 \pm 2.65$ & $4.44 \pm 0.29^{* *}$ \\
Group II & $35.29 \pm 4.31$ & $4.57 \pm 0.38^{*}$ \\
Group III & $36.24 \pm 4.97$ & $4.54 \pm 0.29^{*}$ \\
Group IV & $37.11 \pm 0.88$ & $5.02 \pm 0.55^{* *}$ \\
\hline
\end{tabular}

Values are means \pm SEM. ${ }^{*} \mathrm{p}<0.05$ and ${ }^{* *} \mathrm{p}<0.01$ are considered statistically significant; n: Number of animals, LSI: Liver-somatic index, SEM: Standard error of mean 
$(\mathrm{p}<0.05), 61.05 \%(\mathrm{p}<0.05)$ and $62.27 \%(\mathrm{p}<0.01)$ correspondingly in Groups I, II, III and IV due to Cr (VI) toxicity.

Fig. 1 represents that the IDH activity in mice liver increased in Groups II, III and IV where gradually higher doses of chromium were administered. The increase was found to be $15.48 \%$ ( $p<0.01$ ), 33.58\% $(\mathrm{p}<0.01)$ and $48.88 \%(\mathrm{p}<0.05)$, respectively; but in Group I the IDH activity was slightly decreased by $26.49 \%(\mathrm{p}<0.05)$ at the lowest dose of chromium exposure.

The result presented in Fig. 2 reveals that chromium treatment at the present doses and duration significantly decreased the SDH activity in first two groups (Groups I and II). In those groups, the decrease was noted as $9.33 \%(\mathrm{p}<0.05)$ and $20 \%(\mathrm{p}<0.001)$, respectively. On the other hand, increased activity of the enzyme was observed in Groups III and IV, indicating stimulating effect of hexavalent chromium by $61.33 \%(\mathrm{p}<0.01)$ and $91.33 \%(\mathrm{p}<0.01)$ at higher doses.

Fig. 3 indicates that the MDH activity in mice liver was significantly increased in Groups I and II by 76.07\% ( $\mathrm{p}<0.001)$ and $104.29 \%$ $(p<0.01)$, respectively, whereas in next two successive doses of chromium exposure the increased activity of MDH was noted as $20.25 \%$ $(\mathrm{p}<0.05)$ and $12.88 \%(\mathrm{p}>0.01)$, respectively, in Groups III and IV as compared to control.

As represented in Fig. 4, chromium intoxication significantly decreased NADH-ubiquinone $\mathrm{C}$ oxidoreductase activity in all the groups of mice in comparison to the control value. The percentage changes were observed as $87.24 \%(\mathrm{p}<0.01), 79.95 \%(\mathrm{p}<0.01), 56.15 \%(\mathrm{p}<0.001)$ and $72.44 \%$ ( $\mathrm{p}<0.01)$ in Groups I, II, III, IV, respectively.

Table 3 represents that the liver protein content was decreased in a dose-dependent manner significantly by $8.06 \%(\mathrm{p}<0.001), 24.78 \%$ $(\mathrm{p}<0.001), 35.98 \%(\mathrm{p}<0.05)$ and $55.45 \%(\mathrm{p}<0.01)$, respectively, at gradually increasing doses of exposure.

The free amino nitrogen level was elevated with increased doses of chromium by $345.78 \%(\mathrm{p}<0.05), 590.9 \%(\mathrm{p}<0.05), 645.46 \%(\mathrm{p}<0.01)$ and $6381.82 \%(\mathrm{p}<0.05)$ in Groups I, II, III, IV, respectively (Table 3).

The GPT activity in liver was increased by $68.44 \%(\mathrm{p}<0.01), 96.56 \%$ $(\mathrm{p}<0.05), 133.68 \%(\mathrm{p}<0.05)$ and $176.46 \%(\mathrm{p}<0.01)$ from Group I to Group IV. The GOT activity was also elevated in chromium exposed mice liver by $19.08 \%(\mathrm{p}<0.05), 59.28 \%(\mathrm{p}<0.01), 109.12 \%(\mathrm{p}<0.01)$ and $144.67 \%(\mathrm{p}<0.05)$ in Groups I, II, III and IV, consecutively as compared to the control (Table 3)

In Fig. 5, it further reveals the hepatotoxic effect of Cr (VI) exposure where it points out significant alteration in normal pattern of hepatic radiation and hypercellularity near to the central vain. It also shows the hepatic steatosis and excessive microvesicular inflammation in the liver tissue.

\section{DISCUSSION}

Environmental pollutants are known to alter the physiological and biochemical status of the animals by inducing changes in the activity of several enzymes and metabolites. Heavy metals are non-degradable pollutants in environment which easily enter into the organisms through food and respiratory surfaces, affecting their physiological

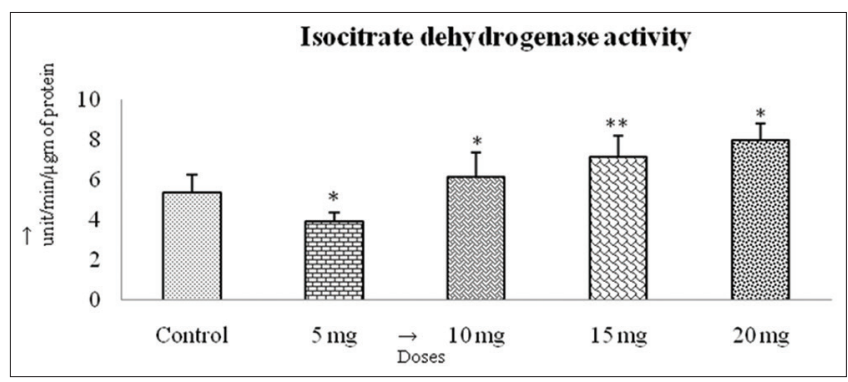

Fig. 1: Dose-dependent changes in the isocitrate dehydrogenase enzyme activity in mice liver after $\mathrm{Cr}$ (VI) exposure. Values are means \pm standard error of mean. ${ }^{*} p<0.05$ and ${ }^{* *} p<0.01$ are considered as statistically significant. $X$-axis represents different doses of chromium and $\mathrm{Y}$-axis represents the unit

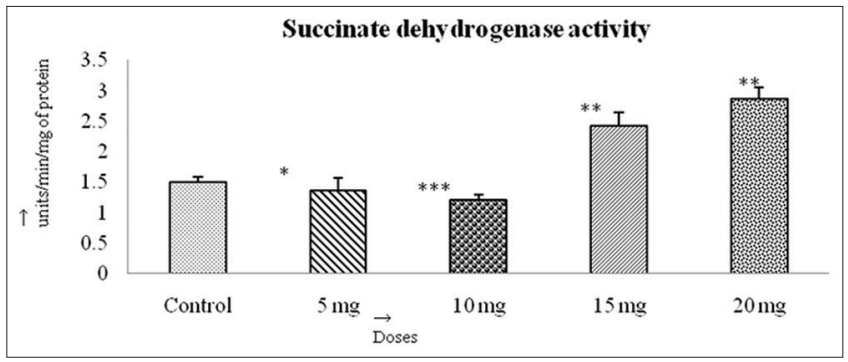

Fig. 2: Dose-dependent effects of chromium on succinate dehydrogenase enzyme activity in hepatocytes of mice. Values are means \pm standard error of mean. ${ }^{*} \mathbf{p}<0.05,{ }^{* *} \mathrm{p}<0.01$ are considered statistically significant and ${ }^{* * *} \mathbf{p}<0.001$ indicates very high significance of difference between control and treated groups. $\mathrm{X}$-axis represents different doses of chromium and $\mathrm{Y}$-axis represents the unit

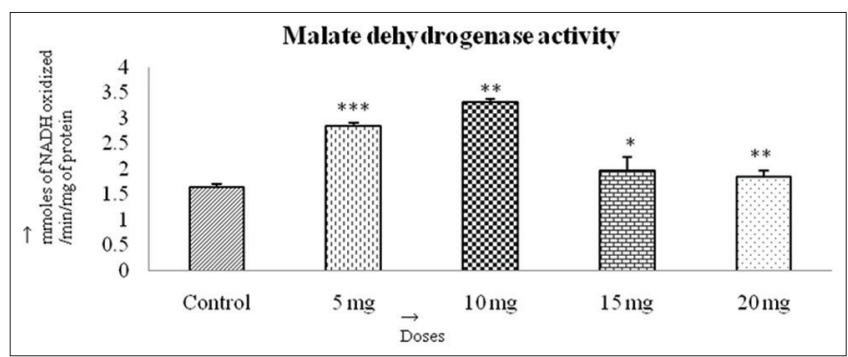

Fig. 3: Dose-dependent alteration of malate dehydrogenase enzyme activity in chromium exposed mice hepatocyte. Values are means \pm standard error of mean. ${ }^{*} \mathbf{p}<0.05,{ }^{* *} \mathrm{p}<0.01$ are considered statistically significant and ${ }^{* * *} \mathbf{p}<0.001$ indicates very high significance of difference between control and treated groups. $\mathrm{X}$-axis represents different doses of chromium and Y-axis represents the unit

Table 2: Changes in blood glucose, liver pyruvate, and glycogen contents due to different doses of hexavalent chromium treatment

\begin{tabular}{llll}
\hline Groups of animals $(\mathbf{n}=\mathbf{6})$ & Blood glucose $\mathbf{( m g / d )}$ & Pyruvic acid content in hepatic tissue (mg\%) & $\begin{array}{l}\text { Glycogen content } \\
\text { tissue) }\end{array}$ \\
& & & $101.38 \pm 2.23$ \\
\hline Control & $177.04 \pm 3.07$ & $156.98 \pm 3.42$ & $78.46 \pm 1.29^{* *}$ \\
Group I & $144.35 \pm 2.65^{* *}$ & $91.04 \pm 2.84^{*}$ & $72.68 \pm 1.38^{* *}$ \\
Group II & $72.64 \pm 2.31^{* *}$ & $79.56 \pm 1.26^{* *}$ & $68.42 \pm 0.86^{*}$ \\
Group III & $84.50 \pm 1.97^{* *}$ & $61.48 \pm 1.84^{* *}$ & $28.97 \pm 0.55^{* *}$ \\
Group IV & $154.42 \pm 2.88^{* *}$ & $59.56 \pm 1.64^{*}$ & \\
\hline
\end{tabular}

Values are means \pm SEM. ${ }^{*} \mathrm{p}<0.05$ and ${ }^{* *} \mathrm{p}<0.01$ are considered statistically significant; $\mathrm{n}$ : Number of animals, SEM: Standard error of mean 
Table 3: Changes in total protein content, GPT and GOT activities and free amino nitrogen content in hepatic tissue following chromium exposure

\begin{tabular}{lllll}
\hline Groups of animals $(\mathbf{n}=\mathbf{6})$ & $\begin{array}{l}\text { Total protein content in } \\
\text { hepatic tissue } \mathbf{( m g \% )}\end{array}$ & $\begin{array}{l}\text { GPT activity unit/mg of } \\
\text { tissue }\end{array}$ & $\begin{array}{l}\text { GOT activity unit/mg of } \\
\text { tissue }\end{array}$ & Free amino nitrogen mg\% \\
\hline Control & $82.92 \pm 2.24$ & $135.26 \pm 1.78$ & $221.42 \pm 2.01$ & $0.11 \pm 0.23$ \\
Group I & $76.24 \pm 1.32^{* * *}$ & $227.82 \pm 0.29^{* *}$ & $263.68 \pm 4.29^{*}$ & $0.49 \pm 0.09^{*}$ \\
Group II & $62.38 \pm 1.54^{* * *}$ & $265.88 \pm 1.92^{*}$ & $352.72 \pm 5.1^{*}$ & $0.76 \pm 0.05^{*}$ \\
Group III & $53.08 \pm 2.29^{*}$ & $316.08 \pm 3.29^{*}$ & $463.02 \pm 7.29^{* *}$ & $0.82 \pm 0.19^{* *}$ \\
Group IV & $38.94 \pm 1.95^{*}$ & $373.94 \pm 5.55^{* *}$ & $541.75 \pm 7.55^{*}$ & $0.86 \pm 0.55^{*}$ \\
\hline
\end{tabular}

Values are means \pm SEM. ${ }^{*} \mathrm{p}<0.05,{ }^{* *} \mathrm{p}<0.01$ and ${ }^{* * *} \mathrm{p}<0.001$ are considered statistically significant; $\mathrm{n}$ : Number of animals, SEM: Standard error of mean, GPT: Glutamate pyruvate transaminase, GOT: Glutamate-oxaloacetate transaminase

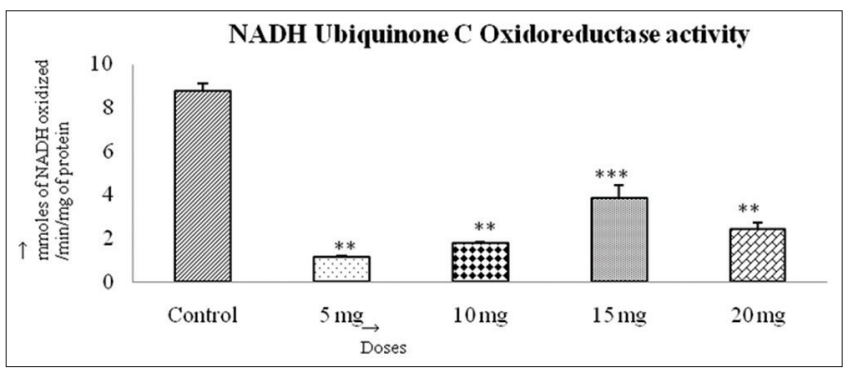

Fig. 4: Variation in nicotinamide adenine dinucleotide ubiquinone $\mathrm{C}$ oxidoreductase activity following $\mathrm{Cr}$ (VI) treatment in liver tissue of experimental mice. Values are means \pm standard error of mean. ${ }^{* *} \mathbf{p}<0.01$ is considered statistically significant and ${ }^{* * *} \mathbf{p}<0.001$ is considered as statistically highly significant. $\mathrm{X}$-axis represents different doses of chromium and Y-axis represents the unit
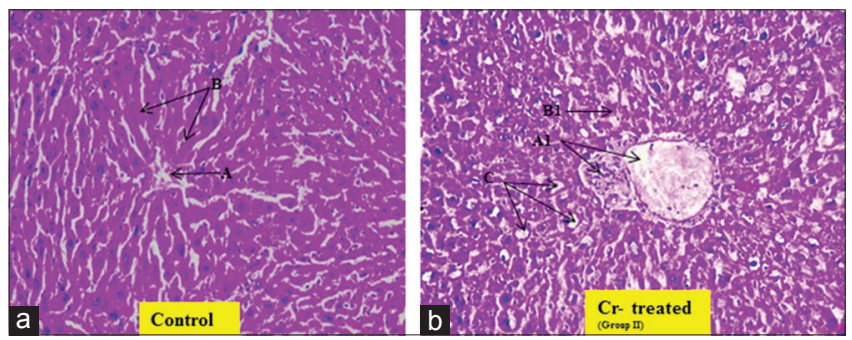

Fig. 5: Altered histopathological characters of liver tissue after chromium exposure. (a) Control: (A) regular portal vain (B) standard hepatocellular radiation, (b) Cr-treated: (A1) inflamed portal vein with hypercellularity in adjacent area

(B1) disintegrated normal radiating pattern of hepatocytes (C) steatohepatitis with steatosis with number of macrovesicular inflammatory foci (hematoxylin-eosin stain, ×20 magnification)

functions [16]. Most of the living organisms derive energy by the metabolic breakdown of carbohydrates. The chief carbohydrate in the tissue is glycogen, while glucose is utilizable sugar found in the tissue and body fluids. Glycogen which is stored reversibly converted into glucose under the influence of hormone-mediated enzyme activities [33]. Moreover, the equilibrium between gluconeogenesis and glycogenolysis tends to maintain the blood sugar at a steady state. The oxidation of glucose is mediated by catabolic pathways, viz., glycolysis, Kreb's cycle, electron transport system and hexose monophosphate shunt which constitute the major segments of carbohydrate metabolism [34]. This study explores some new information regarding the differential effect of hexavalent chromium in a dose-dependent manner on certain aspects of glucose metabolism in mice model.

This study shows that the LSI significantly increased in all groups of chromium exposed mice. Although the body weights of the treated animals were not significantly altered, significant change in liver weight in respect to the body weight was noted after chromium intoxication at the present dose and duration. Alteration in the LSI reflects hostile effect to hepatocellular metabolism and energy storage mechanism in freshwater fish model [35]. These findings are also supported by the fact that hexavalent chromium could induce thickening of blood vessel and perivascular inflammation in various vital organs of the experimental animal $[36,37]$. Hence, it is assumed that due to some inflammatory changes in the intra-hepatocellular spaces, the LSI increased significantly following exposure to chromium.

It is revealed from this study that the blood glucose level significantly decreased in all the chromium exposed animals. The maximum depletion of blood glucose level was found in Group II $(10 \mathrm{mg} / \mathrm{kg})$, which may be due to defective reabsorption of glucose or enhanced excretion of glucose leading to hypoglycemia in chromium exposed mice. Earlier studies on fish model revealed hypoglycemic effect of chromium at a low dose of exposure for 2 months [38]. Experimental studies demonstrated that renal tubular damage and glycosuria are accompanied with the alteration in the activity of different enzymes and proteinuria, which could be the associated factors of hypoglycemia [14]. The decreased glucose may be due to nephritic tissue abnormality or may result from increased rate of glycolysis and excessive metabolism in various vital organs including liver to make up the high energy demand for attenuating the toxic effect of chromium. This is supported by the fact that heavy metal toxicity has the retrogressive effect on compelling metabolic pathways in various experimental animals $[39,40]$. It is further noted that the glycogen depletion is maximum in the high dose exposed group that might be a contributory factor for replenishment of the loss of blood glucose level following exposure to chromium.

Moreover, glycogen is the storage carbohydrate and it occurs mainly in hepatic and muscular tissue and is reversibly converted to blood glucose which serves to maintain blood glucose level when the supply of carbohydrates from the intestinal absorption is inadequate [41]. Metabolic breakdown of glycogen assumes considerable importance in studies involving liver and muscle glycogen levels. The amount of glycogen significantly decreased in the present study in all chromium treated groups as compared with the control value. The decreasing value of glycogen is lower in the low dose exposure group and that is exponentially higher in the increasing doses of toxicant exposure, indicating a dose-dependent decrease in glycogen content in that tissue exposed to chromium. Decrease in glycogen level may be caused by the decrease in its synthetic rate or may be utilized by the animal for its metabolic activities [42]. Maintenance of glycogen reserves is one of the important features of the normal metabolism. Alterations in liver glycogen under situations of stress have been reported, and a significant depletion in tissue glycogen is said to reflect a state of strenuous activity on the part of the experimental animal [43]. A consistent decrease in tissue glycogen reserves observed in this study also suggests enhanced glycogenolysis. Further, the decline in glycogen might be partly due to its utilization in the formation of glycoproteins and glycolipids, which are essential constituents of various cells and other membranes [43]. It is further suggested that the mobilization of carbohydrates for the energy purpose may be a compensatory measure to counter the toxic effects of heavy metals such as chromium and others [44]. 
Pyruvate is the final product of glycolytic reaction and acts as an important intermediate for the citric acid cycle; hence, it is crucial for energy generation [20]. In this study, pyruvate content of hepatocytes was prominently declined with increasing dose of the chromium in the experimental mice. According to Xiao et al. [45] Cr (VI) exerts, its deleterious and negative effects on the bioenergetics of the hepatic tissue by altering the molecular status of metabolites and also by triggering ample amount of oxidative stress molecules. $\mathrm{Cr}$ (VI) inside the cell gets reduced to $\mathrm{Cr}$ (III) by Fenton reaction and this reduced product deport itself as competitive inhibitors for several ATP-dependent kinases those are actively imparted in the glycolytic reactions in cellular processes [46]. This might be an important causative factor for $\mathrm{Cr}$ (VI) mediated unfavorable effect on hepatocellular glycolysis and subsequently decrease in pyruvate production in the liver tissue of $\mathrm{Cr}(\mathrm{VI})$ exposed mice.

The result of this study shows that NADH dehydrogenase activity significantly decreased in all groups of animal owing to the highest degree of toxicity in $5 \mathrm{mg} / \mathrm{kg}$ b.w. Exposure group and less degree of toxicity was found in $15 \mathrm{mg} / \mathrm{kg}$ b.w. Cr (VI) exposure group. NADH dehydrogenase is the entry enzyme of cellular respiration in the mitochondria where it transfers electron from NADH to ubiquinone in the process of electron transport chain. As a result of the reaction, this enzyme translocates four protons $\left(\mathrm{H}^{+}\right)$molecules across the inner membrane of mitochondria per molecule of NADH generating an electrochemical potential to construct high energy ATP. The decreasing activity of NADH dehydrogenase, as observed in the present study may be due to the toxic stress imposed by $\mathrm{Cr}(\mathrm{VI})$ in the mitochondria of the hepatic tissue. The less availability of substrate like NADH is supposed to be involved in chromium-induced decreased NADH dehydrogenase enzyme activity. It was reported that $\mathrm{K}_{2} \mathrm{Cr}_{2} \mathrm{O}_{7}$ triggers structural and enzymatic alterations in rat kidney by single exposure [47]. Such kind of enzymatic alteration is also observed in chromium exposed mice in this study. These findings are further supported by the earlier studies where mitochondrial and cytosolic enzymes for carbohydrate biopolymers undergo alteration and disruption on exposure to $\mathrm{Cr}$ (VI) [48]. The activity of this enzyme differs in a dose-specific manner which may be correlated with relative availability of the substrates such as NADH required for the optimal activity of the enzyme.

IDH is an important enzyme of the mitochondrial matrix and plays a crucial role in citric acid cycle. The enzyme involves in oxidative decarboxylation reaction and produces $\alpha$-ketoglutarate and NADH which are the two important biomolecules for cellular energy. However, the activity of IDH depends on some important co-substrate like NADP and cofactor such as $\mathrm{Mg}^{+2}$ for the final execution of its function. IDH catalyses the irreversible reaction of TCA, allosterically positively regulated by the ADP and inhibited by the ATP and NADH. This study shows a significant decrease in the enzyme activity after exposure to chromium at $5 \mathrm{mg} / \mathrm{kg}$ dose, followed by a gradual increase in the enzyme activity in successive doses, giving a hyperbolic pattern. These indicate a clear dose-specific effect of $\mathrm{Cr}$ (VI) on this enzyme activity. It is postulated that chromium being a potent oxidative stress generator in various organs may induce overproduction of free radicals that might affect the enzymes of the citric acid cycle and tend to decrease their general biological activities [49]. It is suggested that decreased IDH activity might be a causative factor for decreased production of NADH and thus may influence the activity of NADH dehydrogenase.

The present study further demonstrates that the succinate dehydrogenase enzyme activity of liver tissue significantly increased in the higher doses of chromium exposure, whereas at low doses of exposure there was no significant effect of chromium on this enzyme activity. Succinate dehydrogenase is the common enzymological parameter for both citric acid cycle and electron transport chain. In electron transport chain, it acts as the mitochondrial complex II and oxidizes succinate to fumarate, and at the same time, it also reduces the ubiquinone thus completing its programed function in oxidative phosphorylation pathway as well as citric acid cycle. Hypoglycemic condition enhances the beta oxidation rate thus resulting in the production of abundant number ketone bodies which in turn triggers enhanced energy coupling reaction for ATP production in mitochondria through improving and maintaining reduced ubiquinone pool in the tissue [50]. Increased activity of succinate dehydrogenase was observed in hypoglycemia threatened cardiomyocytes [50]. Enhanced glucose and protein excretion with decreased activities of alkaline phosphatase, glucose-6-phosphatase and succinate dehydrogenase in nephritic tissue were observed in subchronic chromium intoxication [49].

Changes in MDH activity reveal that chromium exposure at the present dose and duration caused gradual increase in the enzyme activity up to $10 \mathrm{mg} / \mathrm{kg}$ dose of exposure, followed by declining activity of the enzyme at higher doses of chromium treatment. The MDHcatalyses the NAD/NADH-dependent interconversion of the substrates like malate and oxaloacetate. This reaction plays a key part in the malate/aspartate shuttle across the mitochondrial membrane, and in the TCA within the mitochondrial matrix. Reports are available in support of alteration and disruption of mitochondrial and cytosolic enzymes for carbohydrate biopolymers on exposure to $\mathrm{Cr}$ (VI) [48]. Enhanced of MDH activity at low doses of chromium exposure indicates stimulating effect of chromium on enzyme activity to facilitate the production of energy via TCA cycle in hypoglycaemic-stressed animals. On the other hand, an adaptive mechanism was gradually developed to maintain equilibrium in energy production as a result of high dosage of chromium exposure.

A typical physicochemical commotion of the SDH and NADH dehydrogenase, key parameters of electron transport chain produces an unfavorable condition in the mitochondrial inner environment which may hamper the final execution of energy production in terms of ATP. It is reported that heavy metal can induce the proton leakage from ETC which also contribute for the stress radical generation which in turn can hamper the mitochondrial enzyme system concerning the energy production [51]. In the present study, chromium exposure significantly decreased the activity of NADH dehydrogenase, which was mostly affected in the lowest dose of exposure indicating that the mitochondrial electron transport chain is sensitive to low dose of chromium. Mitochondrial complex I is one of the main sites where the premature electron leakage causes the production of superoxide in the presence of oxygen. Hence, the inhibited NADH dehydrogenase activity due to chromium exposure may enhance the accumulation of free electrons and consequently superoxide anions producing oxidative stress.

Elevated transaminases activity recognizes hepatic toxicity with chromium administration [52]. It is well established that transaminase activity enhanced with ill health of hepatocytes and also increases protein degradation in the specific tissue [51]. Transaminases are also responsible as supplier of gluconeogenic intermediates and other biochemical pathways [54]. Tissue protein degradation and increased GPT and GPT activity further promote vulnerable situation inside the hepatocytes leading to the severe cellular damage by the $\mathrm{Cr}$ (VI). Free amino nitrogen content was prominently increased in the present study and reveals that $\mathrm{Cr}$ (VI) significantly increases the protein degradation and enriches amino acid pool for further utilization in energy production, cellular reparation and may be due to maintain the homeostatic condition between the important metabolic pathways in the liver during toxic situation [55].

Other than biochemical changes chromium exposure at the dose of $10 \mathrm{mg} / \mathrm{kg}$ body for the present duration caused marked morphological changes in liver tissue as evidenced by the formation of steatosis and altered radiating pattern of hepatic cells. These findings thus substantiate hepatic tissue damage-promoting metabolic dysfunctions.

\section{CONCLUSION}

In a nutshell, the successive study depicts that $\mathrm{Cr}$ (VI) agitates main bioenergetics of carbohydrate metabolism by conflicting with normal physicochemical attributes of several substrates and enzymes of 
citric acid cycle as well as electron transport chain. Hypoglycemia and retardation of glycolysis are evidenced in chromium-induced toxic manifestation. It also interferes with liver glycogen content in a great extent thus may serve as a compensatory mechanism to hypoglycemic situation. The study reveals that the citric acid cycle enzyme activities were abruptly changed with differential doses of $\mathrm{Cr}(\mathrm{VI})$ exposure and the activity of mitochondrial complex I was also seriously hampered with this heavy metal. $\mathrm{Cr}(\mathrm{VI})$, being a free radical generator may acquire capability of thickening the blood vessel, perivascular inflammation leading to alteration of LSI. Histopathological alteration showing steatosis in the liver also supports the changes in liver weight. Thus, it may be concluded that hexavalent chromium having the quality to disturb hepatic energy metabolism alters substrate and enzymological parameters of the glycolysis, citric acid cycle, and mitochondrial electron transport chain in a dose-specific manner.

\section{ACKNOWLEDGMENTS}

The authors are grateful to the University Grants Commission, New Delhi for providing Non-NET PhD fellowship to the first author for carrying out this research work. The authors gratefully acknowledge the infrastructural assistance received from the State Biotech Hub, Tripura University.

\section{REFERENCES}

1. El-Bakry RH, Tawfik SM. Histological study of the effect of potassium dichromate on the thyroid follicular cells of adult male albino rat and the possible protective role of ascorbic acid (vitamin C). J Microsc Ultrastruct 2014;2(3):37-50.

2. Barceloux DG. Chromium. J Toxicol Clin Toxicol 1999;37(2):173-94.

3. Ahamed MN, Chandrasekaran N, Mukherjee A. Biochemical analysis of tannery effluent. Int J Pharm Pharm Sci 2014;6:644-5.

4. Soudani N, Troudi A, Amara IB, Bouaziz H, Boudawara T, Zeghal N. Ameliorating effect of selenium on chromium (VI)-induced oxidative damage in the brain of adult rats. J Physiol Biochem 2012;68(3):397-409.

5. Banerjee S, Das B, Umlong MI, Devi RR, Kalita H, Saikia BL, et al. Heavy metal contaminants of underground water in Indo-Bangla border districts of Tripura, India. Int J ChemTech Res 2011;3:516-22.

6. Sangwan P, Kumar V, Joshi UN. Effect of chromium(VI) toxicity on enzymes of nitrogen metabolism in clusterbean (Cyamopsis tetragonoloba L.). Enzyme Res 2014;2014:784036.

7. Travacio M, Polo JM, Llesuy S. Chromium (VI) induces oxidative stress in the mouse brain. Toxicology 2001;162(2):139-48.

8. O'Brien T, Xu J, Patierno SR. Effects of glutathione on chromiuminduced DNA crosslinking and DNA polymerase arrest. Mol Cell Biochem 2001;222(1-2):173-82.

9. Susa N, Ueno S, Furukawa Y, Sugiyama M. Protective effect of vitamin $\mathrm{E}$ on chromium (VI)-induced cytotoxicity and lipid peroxidation in primary cultures of rat hepatocytes. Arch Toxicol 1996;71(1-2):20-4.

10. Wiegand HJ, Ottenwalder H, Bolt HM. Bioavailability and metabolism of hexavalent chromium compounds. Toxicol Environ Chem 1987; 14:263-75.

11. Valko M, Morris H, Cronin MT. Metals, toxicity and oxidative stress. Curr Med Chem 2005;12(10):1161-208.

12. He B, Yun ZJ, Shi JB. Research progress of heavy metal pollution in China: Sources, analytical methods, status, and toxicity. Chin Sci Bull 2013;58:134-40.

13. Shati AA. Ameliorative effect of vitamin $\mathrm{E}$ on potassium dichromateinduced hepatotoxicity in rats. J King Saud Univ Sci 2013;26:181-90.

14. Soudani N, Ben Amara I, Sefi M, Boudawara T, Zeghal N. Effects of selenium on chromium (VI)-induced hepatotoxicity in adult rats. Exp Toxicol Pathol 2011;63(6):541-8.

15. Laborda R, Díaz-Mayans J, Núñez A. Nephrotoxic and hepatotoxic effects of chromium compounds in rats. Bull Environ Contam Toxicol 1986;36(3):332-6.

16. Soudani N, Rafrafi M, Ben Amara I, Hakim A, Troudi A, Zeghal KM, et al. Oxidative stress-related lung dysfunction by chromium(VI): Alleviation by Citrus aurantium L. J Physiol Biochem 2013;69(2):239-53.

17. Hamid Z, Zahoor I, Haq E. Arnebia benthamii aggravates potassium dichromate induced hepatotoxicity in wistar rats. Int J Pharm Chem Biol Sci 2014;4(2):234-40.

18. Rao VM, Parekh SS, Chawla LS. Vitamin-E supplementation ameliorates chromium - and or nickel induced oxidative stress in vivo. J Health Sci 2006;52(2):142-7.
19. Kumar A, Rana SV. Enzymological effects of hexavalent chromium in the rat kidney. Int J Tissue React 1984;6(2):135-9.

20. Abreu PL, Ferreira LM, Alpoim MC, Urbano AM. Impact of hexavalent chromium on mammalian cell bioenergetics: Phenotypic changes, molecular basis and potential relevance to chromate-induced lung cancer. Biometals 2014;27(3):409-43.

21. Dutta M, Chattopadhyay A, Bose G, Ghosh A, Banerjee A, Bandyopadhyay $\mathrm{D}$, et al. Aqueous bark extract of Terminalia arjuna protects against high fat diet aggravated arsenic-induced oxidative stress in rat heart and liver: Involvement of antioxidant mechanisms. J Pharm Res 2014;8(9):1285-302.

22. Krishnaiah C, Reddy KP. Dose dependent effects of fluoride on neurochemical milieu in the hippocampus and neocortex of rat brain. Fluoride 2007;40(2):101-10.

23. Montgomery R. Determination glycogen. Arch Biochem Biophys 1957;67(2):378-86.

24. Barham D, Trinder P. An improved colour reagent for the determination of blood glucose by the oxidase system. Analyst 1972;97(151):142-5.

25. Segal S, Blair AE, Wyngaarden JB. An enzymatic spectrophotometric method for the determination of pyruvic acid in blood. J Lab Clin Med 1956;48(1):137-43.

26. King J. Isocitrate dehydrogenase. Practical Clinical Enzymology. London: Nostrand Co.; 1965

27. Dutta M, Chattopadhyay A, Bose G, Ghosh A, Banerjee A, Bandyopadhyay D, et al. Aqueous bark extract of Terminalia arjuna protects against high fat diet aggravated arsenic-induced oxidative stress in rat heart and liver: Involvement of antioxidant mechanisms. J Pharm Res 2014;8(9):1285-302.

28. Mehler AH, Kornberg A, Grisolia S, Ochoa S. The enzymatic mechanism of oxidation-reductions between malate or isocitrate and pyruvate. J Biol Chem 1948;174(3):961-77.

29. Minakami S, Ringler RL, Singer TP. Studies on the respiratory chainlinked dihydrodiphosphopyridine nucleotide dehydrogenase. I. Assay of the enzyme in particulate and in soluble preparations. J Biol Chem 1962;237:569-76.

30. Lowry OH, Rosebrough NJ, Farr AL, Randall RJ. Protein measurement with the Folin phenol reagent. J Biol Chem 1951;193(1):265-75

31. Rosen H. A modified ninhydrin colorimetric analysis for amino acids. Arch Biochem Biophys 1957;67(1):10-5.

32. Reitman S, Frankel S. A colorimetric method for the determination of serum glutamic oxalacetic and glutamic pyruvic transaminases. Am J Clin Pathol 1957;28(1):56-63.

33. Nygren J, Thorell A, Ljungqvist O. Preoperative oral carbohydrate therapy. Curr Opin Anaesthesiol 2015;28(3):364-9.

34. Hall KD, Bemis T, Brychta R, Chen KY, Courville A, Crayner EJ, et al. Calorie for calorie, dietary fat restriction results in more body fat loss than carbohydrate restriction in people with obesity. Cell Metab 2015;22(3):427-36.

35. Busacker GP, Adelman IR, Goolish EM. Growth. Methods for Fish Biology. Bethesda, Maryland: American Fish Society; 1990.

36. Pedraza-Chaverri J, Cárdenas-Rodríguez $\mathrm{N}$, Orozco-Ibarra $\mathrm{M}$, Pérez-Rojas JM. Medicinal properties of mangosteen (Garcinia mangostana). Food Chem Toxicol 2008;46(10):3227-39.

37. García-Niño WR, Pedraza-Chaverrí J. Protective effect of curcumin against heavy metals-induced liver damage. Food Chem Toxicol 2014;69:182-201.

38. Sastry KV, Sunita K. Enzymological and biochemical changes produced by chronic chromium exposure in a teleost fish, Channa punctatus. Toxicol Lett 1983;16(1-2):9-15.

39. Singh R, Gautam N, Mishra A, Gupta R. Heavy metals and living systems: An overview. Indian J Pharmacol 2011;43(3):246-53.

40. Arya A, Sharma GD. Combined effects of cadmium and mercury on some biochemical and histochemical changes in liver, kidney and gills of Channa punctatus (Bloch). Int J Pharm Pharm Sci 2015;7(8):117-20.

41. Sharma BR, Rhyu DY. Lespedeza davurica (Lax.) Schindl. extract protects against cytokine-induced $\beta$-cell damage and streptozotocininduced diabetes. Biomed Res Int 2015;2015:169256.

42. Tewari H, Gill TS, Pant J. Impact of chronic lead poisoning on the hematological and biochemical profiles of a fish, Barbus conchonius (Ham). Bull Environ Contam Toxicol 1987;38(5):748-52.

43. Vijayaram K, Geraldine P, Varadharajan TS, John G, Loganathan P. Cadmium induced changes in the biochemistry of an air breathing fish Anabas scandens. J Ecobiol 1989;1(4):245-51.

44. Levesque HM, Moon TW, Campbell PG, Hontela A. Seasonal variation in carbohydrate and lipid metabolism of yellow perch (Perca flavescens) chronically exposed to metals in the field. Aquat Toxicol 2002;60(3-4):257-67. 
45. Xiao F, Feng X, Zeng M, Guan L, Hu Q, Zhong C. Hexavalent chromium induces energy metabolism disturbance and $\mathrm{p} 53$-dependent cell cycle arrest via reactive oxygen species in L- 02 hepatocytes. Mol Cell Biochem 2012;371(1-2):65-76.

46. Bagchi D, Balmoori J, Bagchi M, Ye X, Williams CB, Stohs SJ. Comparative effects of TCDD, endrin, naphthalene and chromium (VI) on oxidative stress and tissue damage in the liver and brain tissues of mice. Toxicology 2002;175(1-3):73-82.

47. Baines AD. Cell renewal following dichromate induced renal tubular necrosis. An enzyme histochemical study. Am J Pathol 1965;47(5):851-76.

48. Merkur'eva RV, Krasovskii GN, Burmantova NP, Shaternikova IS, Varshavskaia SP. Changes in the enzyme systems of different sites on exposure to certain chemical substances. Gig Sanit 1980;(1):25-8.

49. Franchini I, Mutti A, Cavatorta A, Corradi A, Cosi A, Olivetti G, et al. Nephrotoxicity of chromium. Remarks on an experimental and epidemiological investigation. Contrib Nephrol 1978;10:98-110.

50. Balietti M, Fattoretti P, Giorgetti B, Casoli T, Di-Stefano G, Solazzi M, et al. A ketogenic diet increases succinic dehydrogenase activity in aging cardiomyocytes: Potential protective role against apoptosisinduced heart failure. Ann N Y Acad Sci 2009;1171:377-84.

51. Belyaeva EA. Mitochondrial respiratory chain inhibitors modulate the metal-induced inner mitochondrial membrane permeabilization. Acta Biochim Pol 2010;57(4):435-41

52. Sun H, Brocato J, Costa M. Oral chromium exposure and toxicity. Curr Environ Health Rep 2015;2(3):295-303.

53. Proctor DM, Suh M, Campleman SL, Thompson CM. Assessment of the mode of action for hexavalent chromium-induced lung cancer following inhalation exposures. Toxicology 2014;325:160-79.

54. Dunn A, Chenoweth M, Hemington JG. The relationship of adrenal glucocorticoids to transaminase activity and gluconeogenesis in the intact rat. Biochim Biophys Acta 1971;237(2):192-202.

55. Vutukuru SS. Acute effects of hexavalent chromium on survival, oxygen consumption, haematological parameters and some biochemical profiles of the Indian major carp, Labeo rohita. Int J Environ Res Pub Health 2005;2(3-4):456-62. 